\title{
NEUROPSYCHOLOGICAL EVALUATION OF CHILDREN AFTER ISCHEMIC CEREBROVASCULAR DISEASE
}

\author{
Inês Elcione Guimarães ${ }^{1}$, Sylvia Maria Ciasca², M. Valeriana L.Moura-Ribeiro³
}

\begin{abstract}
The purpose of this study is to associate neuropsychological evaluation with neuroimaging results in children with cerebral tomography indicating ischemic cerebrovascular disease (ICVD). Neuroimaging, neurological exams and neuropsychological instruments were used to evaluate five children. The study revealed that the cognitive and perceptive skills in two children were normal and motor sequele in four cases. The rhythm, visual and speech receptive skills remained unchanged. In four cases the SPECT exam showed regions with hypoperfusion and in four cases the EEG was normal. Neuropsychological, neurological and image indication some degree of sequele demonstrating the importance of follow up of children who had suffered cerebrovascular disease.
\end{abstract}

KEY WORDS: cerebrovascular disease, neuropsychological avaliation, stroke in children.

\begin{abstract}
Avaliação neuropsicológica de crianças após doença cerebrovascular isquêmica
RESUMO - Este estudo teve como objetivo relacionar os dados da avaliação neuropsicológica com exames de neuroimagem em crianças com doença cerebrovascular isquêmica (DCVI) comprovada pela tomografia de crânio. Foram avaliadas cinco crianças através de instrumentos neuropsicológicos, exame neurológico e neuroimagem. $O$ estudo revelou habilidades cognitivas e perceptivas preservadas em duas crianças e sequela motora em quatro. Não houve alterações nas habilidades de ritmo, visual e fala receptiva. SPECT apresentou regiões com hipoperfusão em quatro casos e EEG normal em quatro. Constatou-se comprometimento sequelar neuropsicológico, neurológico e de imagem; o trabalho mostrou a importância do acompanhamento de crianças pós distúrbio cerebral vascular.
\end{abstract}

PALAVRAS-CHAVE: doença cerebrovascular, avaliação neuropsicológica, ictus em crianças.

The progress on the field of imaging has enabled better characterization of the clinical, diagnostic and evolutional prognosis of cerebrovascular disease ${ }^{1-4}$.

Studies on neuropsychological assessments of ischemic cerebrovascular disease (ICVD) during childhood are rare. So, Koelfen et al. ${ }^{5}$ studied eight children who had suffered cerebrovascular disease during the neonatal period, involving the medial cerebral artery. In correlation of the results of the angiography, magnetic resonance image and the neuropsychological tests, mental retardation and hemiparesis were found in seven children, and epilepsy in four.

The purpose of this study, which is part of a more extensive research is: 1) to report the results of the neuropsychological investigation in the follow up of outpatient children diagnosed as having ICVD; 2) to correlate the neuropsychological findings with the neuroimaging results.

\section{METHOD}

Five children with ICVD ( 4 females and 1 male), diagnosted between the ages of 13 months and 7 years, were evaluated. Their neurological, clinical and image reports were compatible with those of ICVD and they were treated, during the acute phase, at the Faculdade de Ciências Médicas da Universidade Estadual de Campinas (UNI(AMP). At time of evaluation, their ages ranged from 4 years 1 month to 11 years 10 months and their school grades were from preschool to $5^{\text {th }}$ grade (middle school).

Children evaluation was performed through: a) neurological examination; b) electroencephalogram (EEG); c) computatorized tomography of the skull (CT); d) single photon emission computed tomography (SPECT); e) Wechsler's Intelligence Scale for Children (WISC) ${ }^{6}$; Visual-Motor Gestalt test (Bender-Santucci) ${ }^{7}$; Luria Nebraska battery (LNB) ${ }^{8}$.

The first evaluation was performed at the acute phase of the disease, and afterwards during evolution.

Division of Pediatric Neurology of the Faculdade de Ciências Médicas (FCM) of Universidade Estadual de Campinas (UNICAMP) Campinas SP, Brazil: ${ }^{1}$ Post-graduation student; ${ }^{2}$ Assistant-Professor; ${ }^{3}$ Associate-Professor.

Received 18 May 2000, received in final form 28 November 2001. Accepted 6 December 2001.

Dra. Inês Elcione Guimarães - Rua Pompéia 34 - 13090-410 Campinas SP - Brasil. FAX: 193788 7483. E-mail: inesguimaraes@ig.com.br 


\section{RESULTS}

Data related to age at stroke, clinical symptoms and evolution of each child are in Table 1. From the neurological aspect it was observed that three patients had recurrent ICVD (Cases 3, 4, 5 ), all cases had left brain hemisphere involvement with right hemiparesis.

Intelligence scale rating was performed in four children; it was normal in two (Cases 1 and 2) and showed mental deficiency in other two (Cases 3 and 4) (Table 2). The Luria Nebraska battery related to ten neurological areas of specific cortical functions showed: rhythm, visual skill and speech receptivity unaltered; and deficits related to immediate memory and motor skills. Bender's Gestalt test revealed adequate perceptive visual-motor performance in two children, and poor results in two (Table 2).

Image results (CT and SPECT) were put together and showed that they had undergone changes except for cerebral perfusion in Case 2 (Table 3).

Table 4 presents a brief evaluation of WISC, LuriaNebraska battery, SPECT, CT and EEG tests for each child.

Table 1. ICVD in children: general data of the acute phase and its evolution.

\begin{tabular}{cccll}
\hline Case & Sex & Age* $^{*}$ & Clinical Condition & Neurological evolution \\
\hline 1 & $\mathrm{M}$ & $5 \mathrm{y}$ & hemiparesis $\mathrm{R}$, convulsive attacks, aphasia, headache & hemiparesis $\mathrm{R}$ \\
2 & $\mathrm{~F}$ & $1,1 \mathrm{y}$ & hemiparesis $\mathrm{R}$ & normal \\
$3^{* *}$ & $\mathrm{~F}$ & $5,2 \mathrm{y}$ & hemiparesis $\mathrm{R}$, fever, abdominal pain & hemiparesis $\mathrm{L}$, visual deficiency \\
$4^{* *}$ & $\mathrm{~F}$ & $7 \mathrm{y}$ & hemiparesis $\mathrm{R}$, dysarthria, convulsive attacks & hemiparesis $\mathrm{R}$ \\
$5^{* *}$ & $\mathrm{~F}$ & $1,2 \mathrm{y}$ & hemiparesis $\mathrm{R}$ & hemiparesis $\mathrm{R}$ \\
\hline
\end{tabular}

$y$, year; $F$, female; $M$, male; $R$, right; $L$, left; *at installation; ** recurrence.

Table 2. Neuropsychological results of ICVD evolution.

\begin{tabular}{|c|c|c|c|c|c|c|c|c|c|c|c|c|c|}
\hline \multirow[t]{2}{*}{ Case } & \multirow[t]{2}{*}{ *Age } & \multirow[t]{2}{*}{ WISC } & \multirow[t]{2}{*}{ Bender } & \multicolumn{10}{|c|}{ Luria Nebraska battery } \\
\hline & & & & Motor & Rhythm & Tactile & Visual & Memory & Read & Write & Mat.R. & L.Receptive & L.Expressive \\
\hline 1 & $11,10 y$ & A & O & - & O & O & O & - & O & O & O & O & - \\
\hline 2 & $7,1 y$ & AA & 0 & O & 0 & O & O & - & O & O & O & 0 & O \\
\hline 3 & $8,5 y$ & MD & - & - & 0 & O & O & - & - & - & - & O & - \\
\hline 4 & $10,4 y$ & MD & - & - & 0 & - & $\mathrm{O}$ & - & - & - & - & $\mathrm{O}$ & - \\
\hline 5 & $4,1 y$ & NR & NR & - & 0 & O & 0 & 0 & O & O & O & O & O \\
\hline
\end{tabular}

y, year; A, average; AA, above average; MD, mental deficiency; NR, not realized; Mat. R, mathematical reasoning; L, language; ' , adequate; -, deficit; *at assessment.

Table 3. ICVD: neuroimaging results.

\begin{tabular}{cll}
\hline Case & CT - alterations in acute stage & SPECT - hypoperfusion \\
\hline 1 & L basal ganglia & temporal, temporoparietal, thalamus, L basal ganglia \\
2 & L basal ganglia & normal perfusion \\
$3^{*}$ & R frontal -temporoparietal and L occipital & frontal, bilateral parietal-occipital, primary visual area and L thalamus \\
4 & CAG & L temporoparietal, R parietal-occipital \\
5 & L basal ganglia & L frontal, gyrus cingulli \\
\hline
\end{tabular}

R, right; L, left; CAG, bilateral carotid angiography; *EEG, right temporal paroxysmal disorders. 
Table 4. ICVD: neuropsychological evaluation and results of images and EEG.

\begin{tabular}{cccccc}
\hline Case & WISC & LNb & SPECT & CT* & EEG \\
\hline 1 & A & altered & altered & altered & normal \\
2 & AA & altered & normal & altered & normal \\
3 & MD & altered & altered & altered & altered \\
$4 * *$ & MD & altered & altered & NR & normal \\
5 & NR & altered & altered & altered & normal \\
\hline
\end{tabular}

$A$, average; $A A$, above average; MD, mental deficiency; LNb, Luria - Nebraska battery; NR, not realized; *acute phase; **evaluation 6 months after surgery.

\section{DISCUSSION}

The evolution of the five children with ICVD showed that their motor, cognitive, tactile, perceptive, language, reading, writing, mathematical reasoning, and memory skills were affected; the neuropsychological, neurological and image evaluation, performed on these five children revealed the sequelae. Mental deficiency was confirmed in two children (Cases 3 and 4). In Case 3, with polyarteritis nodosa and recurrent vascular disease, images showed affected cortical and subcortical areas, dysfunction in the cerebral perfusion and paroxysmal right temporal activity in the EEG, and a poor performance in the global neurological investigation. Academic knowledge is relevant in the WISC test and therefore the results suggest that the cerebrovascular damage strongly influenced the poor performance of these children (Cases 3 and 4).

Koelfen et al. ${ }^{5}$, in a prospective follow-up study on 8 children, and Ganesan et al. ${ }^{9}$, in a study on twins, found intellectual impairment and neuropsychological deficits in children with cerebrovascular disease.

In Case 5, the vascular symptoms reccurred 18 months later and affected the subcortical regions of the contralateral hemisphere. It was not possible to perform the WISC and Bender tests because of the chronological age, but the other test performances were adequate for the age group, indicating a preserved intellectual capacity.

When stroke occurred, Case 1 was 5 years old and presented dominance defined to the right hand, and the ICVD affected the left hemisphere resulting in right hemiparesis. Therefore, the functions of the right hand were transferred to the left, which made the child a false lefty, but it was observed that the child still used the right hand for a few movements. This meant that the function was not totally affected, even though there was a structured lesion as show the CT (Table 3).

The site, extension and time of the settlement of the lesion are important aspects in a neurological evaluation; the results obtained in the neuropsychological tests of a developing brain are different from that obtained in an adult patient. So, a greater capacity of cerebral reorganization recovery of functions are expected in children ${ }^{10,11}$. It should be reminded that lesions affecting an immature brain, may compromise several superior structures as has been observed by us and other authors ${ }^{4,5,9}$.

The Luria-Nebraska battery showed that the motor, immediate memory and expressive speech skills are the functions most affected. Deficits in motor skills observed in four of the children may be consequence of the hemiparesis observed in these patients.

Visual-motor perception is a function controlled by cerebral cortex and requires an integration of temporo-parietal-occipital lobes of the non-dominant hemisphere, because these areas are important for the perception of spacial relationship ${ }^{12}$. The Luria Nebraska battery showed that no difficulty was observed regarding visual skill, which suggested that the reception, integration and expression of information were adequate. However, the Bender test proved to be more difficult to be achieved on Cases 3 and 4, probably because they had problems with integration and expression of information, and their SPECT exams agree with hypoperfusion in these cortical areas. As less perfusion was particulary observed on left temporal, left temporo-parietal and left parietal-occipital regions, it is advisable that these areas are important for expressive language, writing, reading, mathematical reasoning, tactile skills, rhythm and immediate memory functions.

The damage was more marked in patients with intellectual performance below the average, or compatible with mental deficiency. The neuropsychological and image exams (SPECT) of monozygotic twins with moyamoya disease, one symptomatic (Case 4) and the other asymptomatic, revealed intellectual retardation, as well as frontal and temporal hypoperfusion in the symptomatic child.

The association of results obtained from the Luria-Nebraska battery and the SPECT exams, showed that the greatest deficit was mediated by areas that had the leastest perfusion, indicating that the level of intelligence was not restricted to a specific area of the brain, but depended of a combination of various structures and cerebral functions. 
Therefore, the analysis of the results obtained using several instruments, showed the importance of the correlation between the damaged areas and the results of neuropsychological tests.

\section{REFERENCES}

1. Sztrilla LAL, Suhaili AR,Prais V, Nork M. Regional cerebral blood perfusion in children with hemiplegia: a SPECT study. Neuropediatrics 1996;27:178-183.

2. Moura-Ribeiro MVL,Ciasca SM, Vale-Cavalcante M, Etchebehere ECSC,Camargo EE. Cerebrovascular disease in neonates:report of three cases with evolutive study and SPECT. Arq Neuropsiquiatr 1999;57:1005-1010.

3. Moura-Ribeiro MVL, Ferreira LS, Montenegro MA, et al. Doença cerebrovascular na infância: II.Aspectos clínicos em 42 casos. Arq Neuropsiquiatr 1999;57:594-598

4. Ciasca SM, Alves HL, Guimarães IE.Comparação das avaliações neuropsicológicas em menina com doença cerebrovascular bilateral (moyamoya) antes e após a intervenção cirúrgica. Arq Neuropsiquiatr $1999 ; 57: 1036-1040$
5. Koelfen W, Freund M, König S, Varnholt V, Rohr H, Schultze C. Results of parenchymal and angiographic magnetic resonance imaging and neuropsychological testing of children after stroke in neonates. Eur J Pediatr 1993;152:1030-1035.

6. Wechsler D. Escala de inteligência Wechsler para crianças: manual. Poppovic AM (trad). Rio de Janeiro: Cepa, 1964.

7. Santucci H, Galifret-Granjon N. Prova gráfica de organização perceptiva. In Zazzo R. Manual para exame psicológico da criança. São Paulo: Mestre Jou,1968:233-265.

8. Golden CV. The Nebraska neuropsychological children's battery. In Reynolds CR, Fletcher-Jansen E. Handbook of clinical child neuropsychology. New York: Plenun Press, 1989:193-204.

9. Ganesan V, Isaac E, Kirkham FJ. Variable presentation of cerebrovascular disease in monovular twins. Develop Med Child Neurol 1997;39:628-631.

10. Antunha ELG. Avaliação neuropsicológica na infância.In Oliveira VB, Bossa NA. Avaliação psicopedagógica da criança de zero a seis anos. 2.Ed.Petrópolis: Vozes,1994:89-121.

11. Lefèvre BH. Neuropsicologia infantil.São Paulo: Sarvier,1989.

12. Colorni ER. Teste gestáltico visomotor Bender e o fracasso escolar: fator lesional ou fator emocional? Temas sobre Desenvolvimento. 1994;4(20)20-24. 